\title{
THEORETICAL AND EXPERIMENTAL MODAL ANALYSIS OF THE CYLINDER UNIT FILLED WITH PUR FOAM
}

\section{TEORETYCZNA I EKSPERYMENTALNA ANALIZA MODALNA ZESPOŁU BĘBNA WCIĄGARKI WYPEŁNIONEGO PIANKĄ POLIURETANOWĄ}

\begin{abstract}
In the paper the dynamic properties of the cylinder unit as a part of the theatre scenography lifting mechanism have been investigated. The noise and vibration problem of the cylinder unit when lifting loads turned out to be the crucial limit in application of the whole mechanism for lifting scenography elements on a theatre stage. The construction of the mechanism was examined and the main source of noise was identified as the cylinder unit. Theoretical modal analysis confirmed that thesis. Experimental modal analyses of the hollow cylinder unit as well as the cylinder with the PUR foam filling were performed. The results showed significant improvement of the dynamic properties due to the vibration amplitude decrease for the first three vibration modes of the filled cylinder. The research method of modal analysis turned out to be highly efficient in dynamic properties determination in the industrial practice. The method of improving the dynamic properties of the mechanical construction by filling closed regions with PUR foam is of a great importance for industrial application and seems to be economically effective.
\end{abstract}

Keywords: dynamic properties, noise and vibration, theoretical and experimental modal analysis, PUR foam.

\begin{abstract}
W artykule przedstawiono badania dynamicznych właściwości zespołu bębna wciagarki stużacej do podnoszenia scenografi teatralnej. Problem nadmiernego hałasu i drgań wciagarki podczas podnoszenia elementów scenografii okazat się istotnym problem użytkowym ograniczającym możliwości zastosowania urządzenia $w$ teatrze. Przeprowadzono analizę konstrukcji mechanizmu wciagarki $i$ wskazano zespót bębna jako źródto nadmiernego hałasu. Tę tezę potwierdzono przeprowadzając teoretyczna analizę modalna zespolu bębna. W części doświadczalnej badań przeprowadzono analizę modalna oryginalnego, pustego zespolu bębna a następnie zespotu wypetnionego pianka poliuretanowa. Otrzymano wyniki badań doświadczalnych, na podstawie których dokonano obserwacji, że amplituda pierwszych trzech postaci drgań swobodnych analizowanego zespotu została znacznie obniżona, co skutkuje znaczną redukcja hałasu generowanego przez bęben wypetniony pianka poliuretanowa. Analiza modalna okazata się wysoce przydatna $w$ praktyce przemystowej $w$ celu określania dynamicznych właściwości urządzenia mechanicznego. Na podstawie wyników przeprowadzonych badań modalnych sformutowano wniosek, że metoda wypetniania zamkniętych obszarów konstrukcji mechanicznych pianka poliuretanowa w celu poprawienia właściwości dynamicznych urzadzenia może być szeroko wykorzystana w praktyce przemystowej ze względu na wysoka skuteczność oraz ważny aspekt ekonomiczny w postaci niskiej ceny takiego rozwiazania.
\end{abstract}

Stowa kluczowe: właściwości dynamiczne, hatas i drgania, teoretyczna i eksperymentalna analiza modalna, pianka poliuretanowa.

\section{Introduction}

Vibration can be considered as an undesired phenomenon in mechanical mechanisms as far as it decreases lifetime of the machine, limits its performance, influences other machines in the neighborhood or induces high level of noise. There are some application areas where the latter reason is referred to as the crucial one. All the measures which must be undertaken in those circumstances focus on either identifying and removing the excitation sources or minimizing harmful results of vibration. When it is not possible to change construction of vibrating mechanism and sources of vibration are beyond control the efficient way to improve machine dynamic behavior parameters is to enhance damping properties of the mechanical system. This approach can be realized as active or passive damping. Active damping methods include application of specially designed and adaptively controlled actuators which counteract the vibration motion and use springs of variable rigidity coefficient, viscous dampers with actively controlled internal flow, dampers with non-newton fluids etc. Those solutions are very efficient when well-tuned but expensive and dif- ficult to be inserted into the existing design. That is why passive ways of vibration damping are the most often applied applications.

To solve the noise and vibration problems and identify the dynamic properties of the mechanical systems new research methods both theoretical and experimental must be applied. In the past three decades, modal analysis has become a major technology in the quest for determining, improving and optimizing dynamic characteristics of engineering structures $[6,8,12]$. It has been successfully applied to solve structural dynamic problems in mechanical $[5,7,9,15,16]$ and aeronautical [14] engineering. Recently modal analysis has also found its broad applications for civil and building [11] structures, biomechanical and harvest [3] problems, space structures, electrics and electronics [2] acoustical instruments [1], transportation [10] and nuclear plants.

The origin of presented research is the technical problem of the curtain lifting mechanism making too much noise to be applied in a theatre. The mechanisms of scenography changing must work smoothly and quietly during a play otherwise they attract the spectators' attention spoiling the art effect. 


\section{The object of research}

The whole mechanism of a scenography lift consists of an electrical motor combined with a reducing gear box, the cylinder unit with bearings supported in the frame of the machine. The cylinder unit is a welded construction of the shaft, two flanges and the cylinder. The cylinder of $1000 \mathrm{~mm}$ long is supported on two flanges which connect it to the main shaft of ca. $1400 \mathrm{~mm}$ long. The elements are mutually located by means of the shapes tolerated as normal running fit. The parts of the unit are connected with standard filled welds. The original construction of the cylinder unit is presented in Fig.1.

On the external surface of the cylinder there is an u-groove distributed helicoidally which is designed to guide a rope winding on the cylinder. The whole construction is made of structural steel. The cylindrical surfaces for bearings are ground to obtain required tolerances. The whole unit mass is ca. $160 \mathrm{~kg}$.

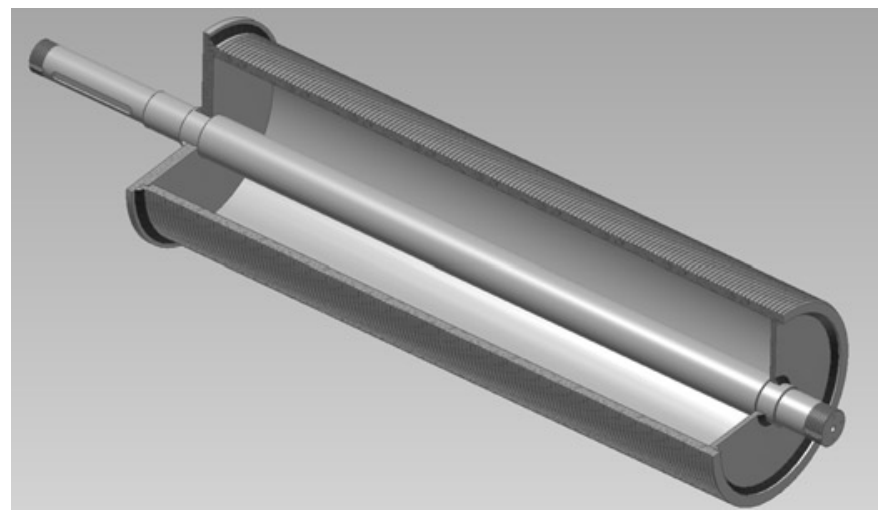

Fig. 1. The original construction of the cylinder unit

The construction presented in Fig.1 is optimal from the strength point of view. However, the hollow region inside the cylinder makes the unit susceptible to dynamic excitation because the cylinder is supported only on both sides without any support along its generating line. That is the reason why the cylinder is prone to vibrating with high amplitude rates which makes loud noise.

\section{Problem definition and proposed solution}

The analysis of the lifting mechanism and the preliminary experimental noise tests showed the source of the highest sound intensity not around the motor and gear but in the middle of the winding cylinder. It proved that the reason of the noise and vibration is an instability of the mechanical system of the cylinder unit of the machine. That fact had to be verified by thorough theoretical and experimental investigation.

The solution of the vibration minimizing problem had to be easy-applicable and inexpensive because the production of the lifting mechanisms should remain competitive. The solution which was chosen was a passive way of vibration damping by inserting additional material of high damping properties into the existing structure. The large region inside the cylinder seemed to be the best space to insert vibration damping material. It needed creating some inlet hole through which the material should be inserted. The other limitation was the density of the material. The overall mass of the lifting mechanism should not be increased too much because all the construction assumptions and solutions could not be altered. Additionally, the applied material should be incombustible. Considering all those limitations and assumptions the PUR foam of low-expansibility was chosen for further research. That material is of low density (ca. $20 \mathrm{~kg} / \mathrm{m}^{3}$ after curing) and very good adhesion properties. Its low-expansibility makes that material structure very advantageous for vibration damping because it has small void spaces after curing.
The proposed solution needs to be investigated numerically and experimentally in order to evaluate the influence of the additional material of PUR foam on the dynamic properties of the whole cylinder unit.

\section{Theoretical and experimental modal analysis}

Modal analysis is the process of determining the inherent dynamic characteristics of a system in forms of natural frequencies, damping factors and mode shapes, and using them to formulate a mathematical model for its dynamic behavior. The formulated mathematical model is referred to as the modal model of the system and the information for the characteristics are known as its modal data [6]. The system must meet several requirements in order to apply the modal analysis method for its examination i.e. it has to be linear, time-invariant and observable and it must obey the Maxwell's reciprocity theorem. These basic prerequisites must be checked and fulfilled prior performing modal analysis test of the system. The modal analysis (MA) can be performed as theoretical, experimental or operational modal analysis. Theoretical MA usually applies Finite Element Method (FEM) to solve dynamic problems of the analyzed structure. The procedures of solving the MA problem are usually implemented in the 3D CAD software systems, which is very convenient because the analyses are performed in the same graphic environment as the design process.

The experimental modal analysis comprises deriving the dynamic properties of analyzed structure by means of experimentally obtained characteristics of input signal - excitation force and corresponding characteristics of vibration response signal of the system (acceleration, velocity or position). The modal identification test is subjected to the prerequisites of the modal analysis method. It returns information in the form which can be applied for further evaluation process in order to achieve the required information on the dynamic properties of the analyzed system. The information can be also applied in the model of the machine when the mathematical form of the obtained characteristics is properly defined. Additionally, the mathematical form of that definition must comply with the actual form of the whole model of analyzed system.

Modal analysis can be considered as transformation of a complex dynamic system into a set of single-degree-of-freedom systems [4, 6]. If the aim of research is to determine frequency of free vibrations of the system, modal analysis can be limited to simple identification modal test for deriving frequency response function (FRF) of the system. FRF is a transfer function and is expressed in frequency domain.

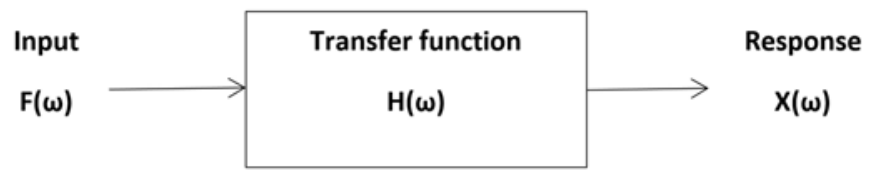

Fig. 2. The linear mechanical system

For the linear system (Fig. 2) the following formula can be expressed-Eq. (1):

$$
X(\omega)=H(\omega) \cdot F(\omega)
$$

The transfer function $\mathrm{H}(\omega)$ is the complex function which is formulated as follows - Eq. (2):

$$
H(\omega)=\frac{X(\omega)}{F(\omega)}
$$


The FRF reflects dynamic properties of the investigated system. It represents relation between the response of the system (e.g. position, velocity, acceleration) and input force for the certain pair of measurement points of response and excitation. The important feature of the frequency response function is the fact, that it describes dynamic properties of the investigated system regardless the type of excitation signal (harmonic, impulse or random) during measurements. The FRF provides qualitative and quantitative evaluation of the dynamic system resonance of the machine tool [13].

The experimental modal analysis procedure can be performed by single input-single output (SISO) method, single input - multiple outputs (SIMO) or multiple inputs - multiple outputs (MIMO). These methods differ not only in the measurement equipment requirements but also in the required aim of the research and the accuracy of the analysis results.

SISO method is used mainly when only two-channel data acquisition measurement system is available and the resultant FRF can be limited to several point of measurement. It is usually applied when impact hammer test is performed (force input signal and acceleration output signal). The method can be applied as roving hammer (fixed accelerometer) or fixed hammer (roving accelerometer) procedure. In practice the roving hammer procedure is much more convenient because it does not require reinstalling the accelerometer from one point of measurement to another as it is in the fixed hammer procedure. The problems arise with normalizing input signal for every measurement point. Therefore averaging procedure must be introduced.

SIMO method enables application of the harmonic exciter as in input signal generator for simultaneous exciting many points of response measurement. It requires multi-channel data acquisition system and gives more accurate results than SISO method, because the same excitation signal is used for all analyzed response points while performing modal analysis.

MIMO is more hardware-requiring method but it returns much thorough information of the analyzed system than SISO or SIMO method. It is usually applied when the multi-channel data acquisition system is available. The selected input points can be excited with different force characteristics in order to enhance accuracy and efficiency of the modal analysis.

In the further analysis the SISO method was applied because of the limitations of the measurement system which was used.

\section{Research method}

The theoretical modal analysis was performed in order to obtain modal shapes and their frequencies of the cylinder unit. The 3D CAD software applied in that study is Autodesk Inventor 2015 Professional. In that system the 3D model of all the parts and welded assembly were created. In order to perform the analysis efficiently some simplifications of the analyzed model were applied. They comprised excluding small holes on the surface of the cylinder and the helicoidal groove. The simplifications were applied in order to speed-up the analysis. In the case of small elements modelling the finite elements dimension must be lower and it increases the number of elements, knots and equations to be solved. The simplifications introduced in the model change the dynamic properties of the whole system slightly but not significantly. The elements materials properties were assigned from the Inventor library according to the construction documentation. Subsequently, the boundary conditions of the analysis were defined.
The theoretical modal analysis requires indicating the support of analyzed construction. For the numerical analysis the cylindrical surfaces of bearing contact were defined as fixed support. The assembly analysis requires definition of contacts among the elements of construction. The default contact type is bonded contact of the surfaces which are closer to each other than tolerance of $0.01 \mathrm{~mm}$. Considering the real way of connecting elements within the construction the bonded contacts were only applied between every weld and welded element. The other automatically created contacts were discarded in analysis. That method of contact definition reflected the real way of elements connection. The finite elements net was created with default settings (tetrahedrons) of the analytical program.

The experimental modal analysis was performed in order to obtain modal shapes, their frequencies and evaluate magnitude rates of the frequency response functions in the resonances of the cylinder unit structure. The impulse excitation was exerted by means of a modal hammer. The response was measured with an accelerometer. The signals both from the hammer and the accelerometer were acquired and analyzed in the PULSE system. The PULSE LITE system [17] by Brüel\&Kjær consists of the measurement module 3560L, the FFT analysis software, the accelerometer 4514 [18] and the modal hammer 8206-003 [19].

The points of input (excitation) and response (acceleration) measurement were chosen on the cylinder and the shaft in one plane because the whole construction is axially symmetrical. The accelerometer was placed in the middle of the cylinder length for in that point one can expect the highest rates of vibration amplitude. The sensor was mounted on the cylinder with the bee wax, which is reported to as one of the best way of connecting the accelerometer to the measured surface [13].

In the case of noise in the output signal the $\mathrm{H} 1$ estimator of FRF [13] is applied the value of which approaches the real FRF with the growing number of measurement repetitions. The $\mathrm{H} 1$ estimator is equal to the cross spectrum, between the response and force, divided by the autospectrum of the force. The H1 estimator minimizes the output noise effect. That is why 3 repetitions of every measurement were applied in the experimental test procedure.

\section{Results of research}

Numerical simulations were performed in the Simulation module of Autodesk Inventor 2015 Professional system. Firstly, the original welded construction of the cylinder unit was examined (Fig.1). The first 20 modes of the hollow unit were investigated. The results obtained in simulation are presented in Table 1.

The modes obtained in numerical simulation are multiplied because analytical software recognizes modes of the same shape distributed in different planes of symmetry. Therefore modes No 3 and 4 are the same modes in two perpendicular planes respectively. The same situation is in the case of the following pairs: 5 and 6, 7 and 8, 9 and 10 etc. From the noise point of view the modes presented in the figures 3, 4 and 5 are of particular interest. These mode shapes can be strong sources of noise. The other shapes refer to the shaft modes which vibrates inside the cylinder.

The legend on the side of graph shows the displacements of the analyzed elements deformed during vibration of certain mode and frequency but it should be noted that these values are introduced into simulation only for comparing purposes. They do not represent real

Table 1. Frequencies of the first 20 modes of the hollow cylinder unit

\begin{tabular}{||c|c|c|c|c|c|c|c|c|c|c|c|}
\hline Mode No & 1 & 2 & 3 & 4 & 5 & $\mathbf{6}$ & 7 & 8 & 9 & 10 \\
\hline Frequency $[\mathrm{Hz}]$ & 191,58 & 243,31 & 247,01 & 247,08 & 520,23 & $\mathbf{5 2 0 , 3 1}$ & 649,62 & 649,82 & 667,17 & 667,48 \\
\hline Mode No & 11 & 12 & 13 & 14 & $\mathbf{1 5}$ & 16 & 17 & 18 & $\mathbf{1 9}$ & 20 \\
\hline Frequency $[\mathrm{Hz}]$ & 772,38 & 785,29 & 1079,32 & 1083,96 & $\mathbf{1 1 0 2 , 4 6}$ & 1103,95 & 1277,07 & 1278,87 & $\mathbf{1 4 5 0 , 9 8}$ & 1508,05 \\
\hline
\end{tabular}




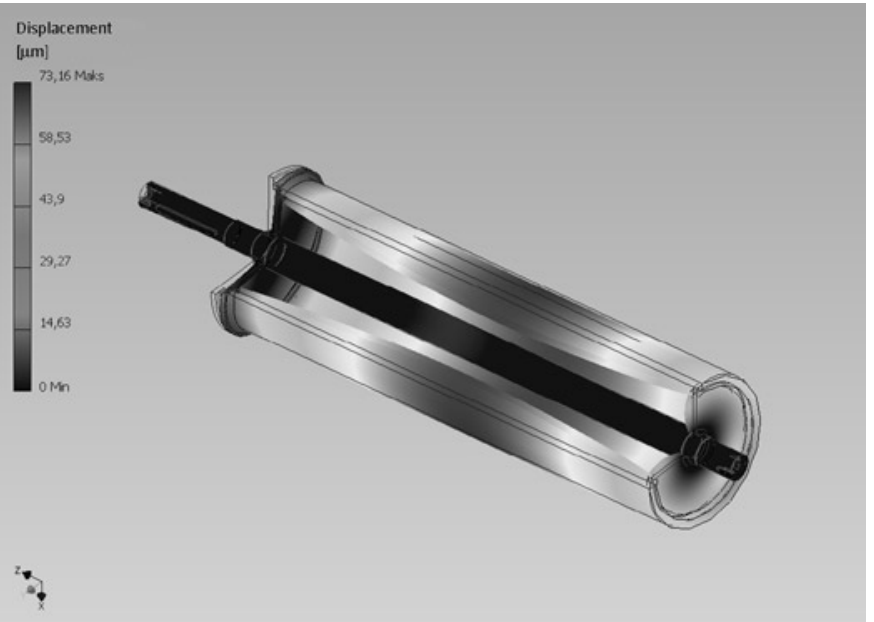

Fig. 3. The $6^{\text {th }}$ mode of the cylinder unit $(520 \mathrm{~Hz})$

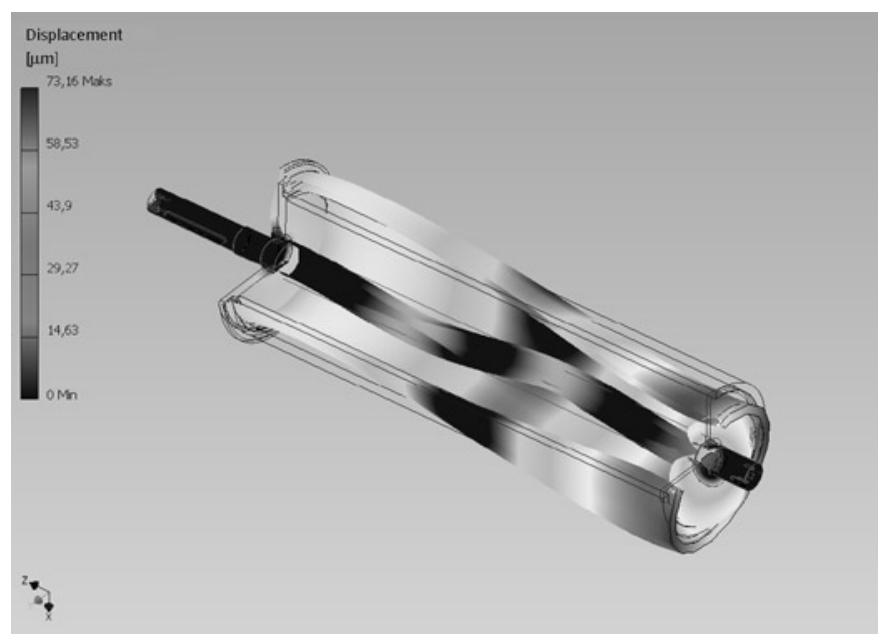

Fig. 4. The $15^{\text {th }}$ mode of the cylinder unit $(1102 \mathrm{~Hz})$

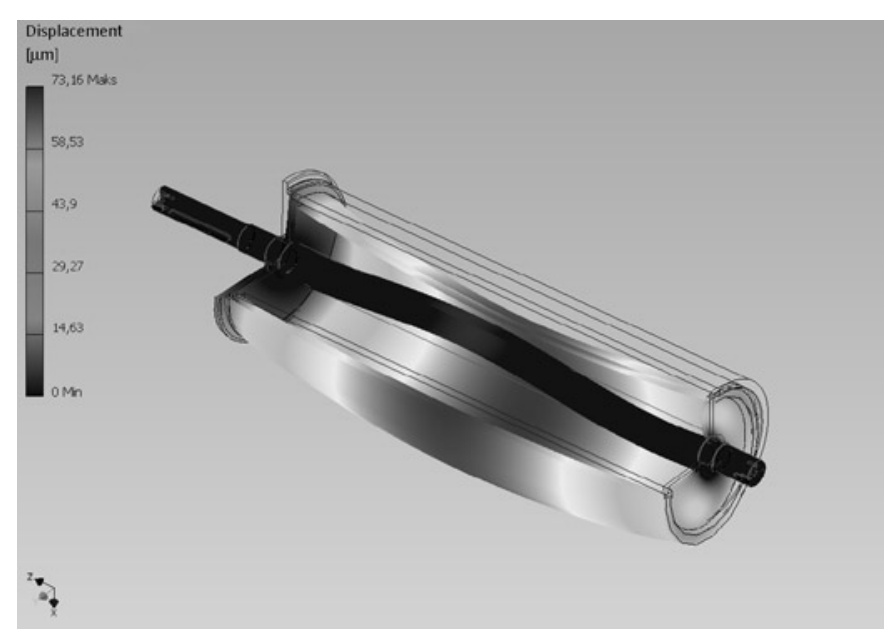

Fig. 5. The $19^{\text {th }}$ mode of the cylinder unit $(1451 \mathrm{~Hz})$

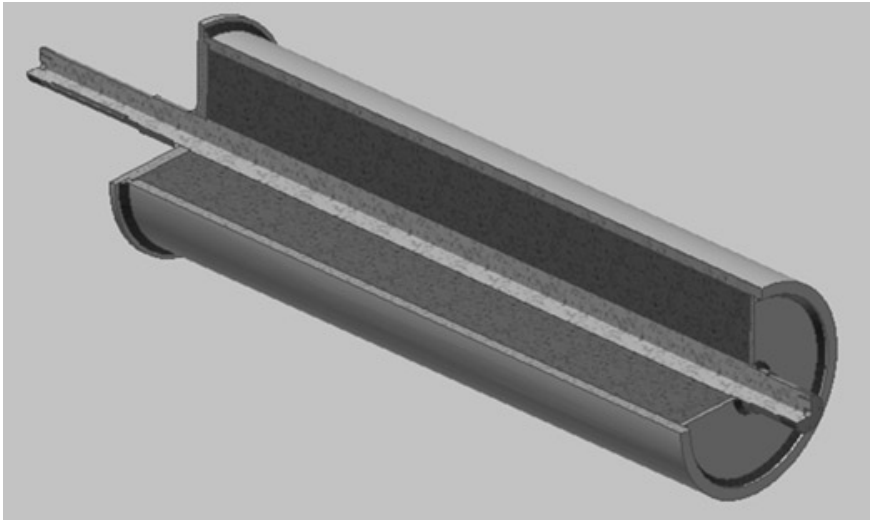

Fig. 6. The modified construction of the cylinder unit

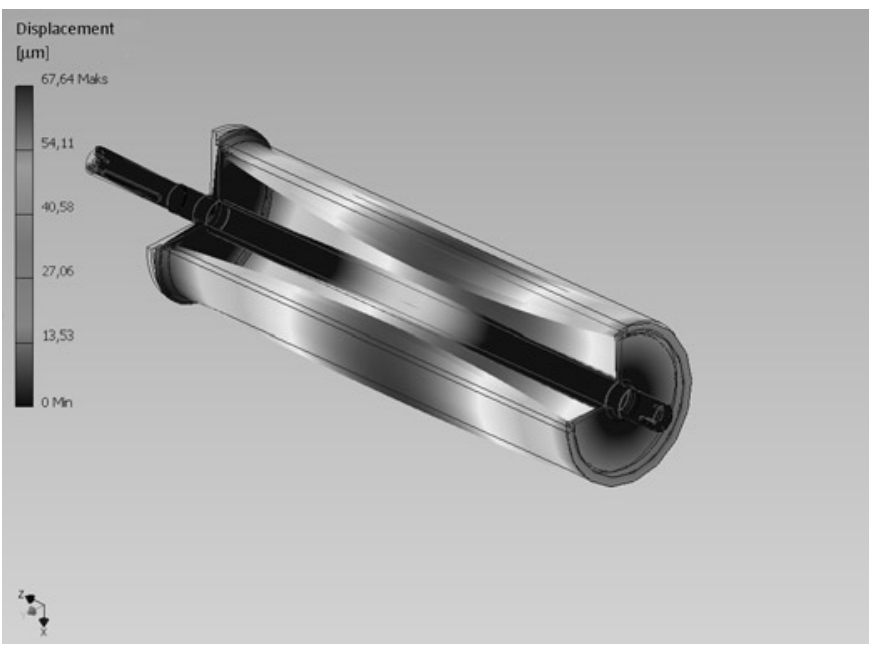

Fig. 7. The $6^{\text {th }}$ mode of the cylinder unit $(560 \mathrm{~Hz})$

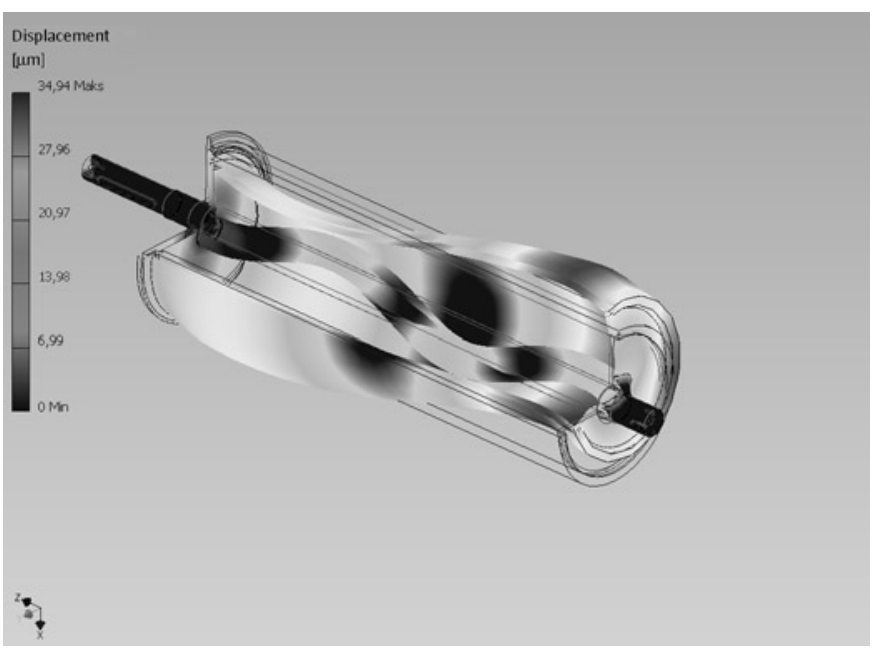

Fig. 8. The $15^{\text {th }}$ mode of the cylinder unit $(1230 \mathrm{~Hz})$

Table 2. Frequencies of the first 20 modes of the modified cylinder unit

\begin{tabular}{||c|c|c|c|c|c|c|c|c|c|c||}
\hline \hline Mode $\mathrm{N}^{\circ}$ & 1 & 2 & 3 & 4 & 5 & $\mathbf{6}$ & 7 & 8 & 9 & 10 \\
\hline Frequency $[\mathrm{Hz}]$ & 294,43 & 294,51 & 300,90 & 358,31 & 557,62 & $\mathbf{5 6 0 , 0 0}$ & 695,12 & 704,57 & 705,36 & 735,48 \\
\hline Mode $\mathrm{N}^{\circ}$ & 11 & 12 & 13 & 14 & $\mathbf{1 5}$ & 16 & 17 & 18 & $\mathbf{1 9}$ & 20 \\
\hline Frequency $[\mathrm{Hz}]$ & 773,27 & 783,97 & 1155,58 & 1226,01 & $\mathbf{1 2 3 0 , 0 0}$ & 1309,49 & 1309,61 & 1420,84 & $\mathbf{1 4 8 0 , 5 9}$ & 1500,36 \\
\hline
\end{tabular}




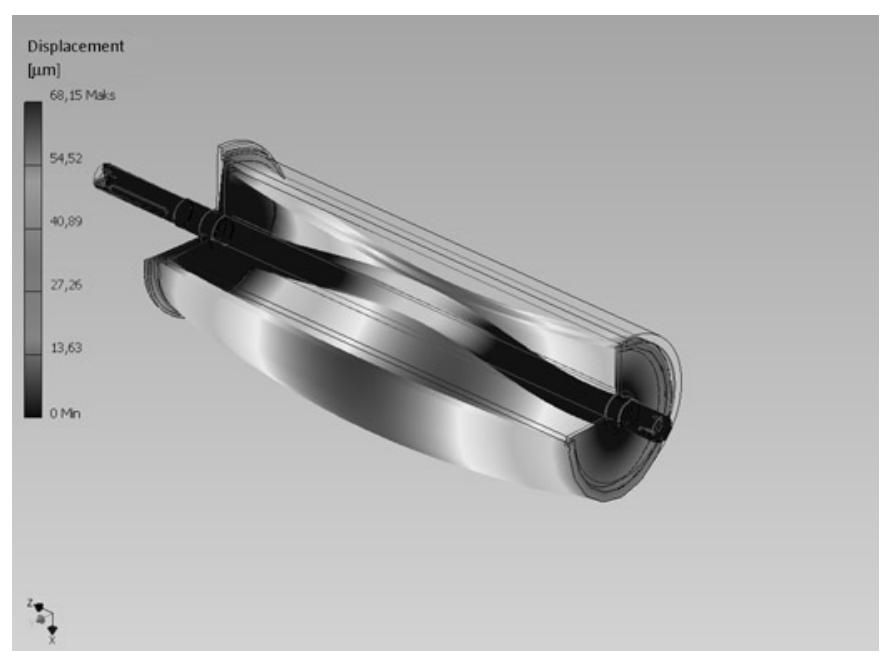

Fig. 9. The $19^{\text {th }}$ mode of the cylinder unit $(1481 \mathrm{~Hz})$

deflections of the elements but reflect damping capabilities of the mechanical system when comparing one boundary situation or construction to another.

Having performed simulations of the original cylinder unit the modification of its constructions was created. The inside of the cylinder element was filled with material of PUR foam (Fig. 6). The material was supposed to be inserted by a hole of about $20 \mathrm{~mm}$ diameter in one flange of the unit. The hole was not modelled in analytical software because it is insignificant for simulation results.

To perform simulation the model of the PUR foam material had to be introduced into Autodesk Inventor Material Library. The parameters of the PUR foam material were obtained from the producer sources and implemented into the Library. Due to the fact that the PUR foam sticks to the metal surfaces strongly the contacts of the material with the steel elements of the unit were taken into consideration and modelled as bonded contacts.

The results obtained with the same boundary conditions are presented in Table 2 .

The frequencies for the corresponding modes of the filled cylinder unit are slightly higher than those of the hollow unit. It is a result of adding lightweight material of considerable stiffness. The modes presented in Fig. 7, 8 and 9 are similar to the corresponding modes of the hollow unit shown in Fig. 3, 4 and 5.

Analyzing the maximum deflection values (the legend in Fig. 3, 4, $5,7,8$ and 9) it can be noted that for the presented modes the rate of deflection for modified construction of the cylinder unit is lower than for hollow cylinder unit.

The numerical modal analysis gave promising results which indicate that it is possible to obtain good results in reality. It is experimental modal analysis which can fully justify the modification of the construction and support the thesis of achieving significantly higher

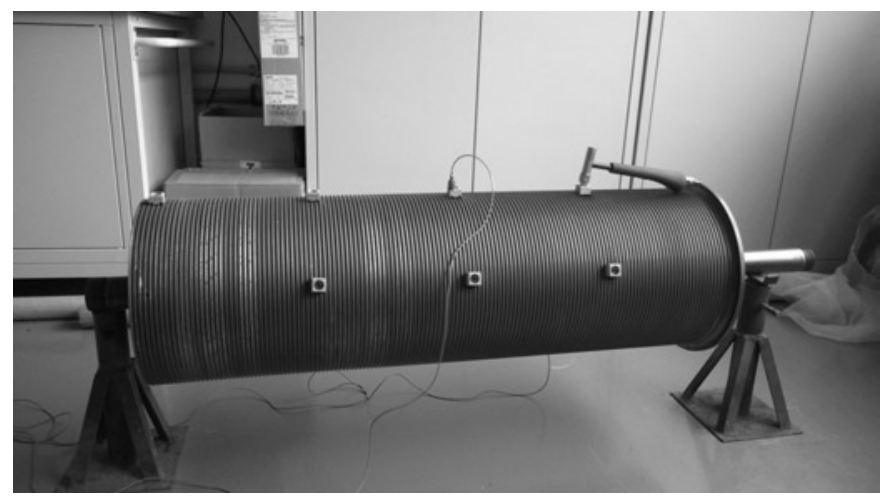

Fig. 10. The modal test rig of the cylinder unit

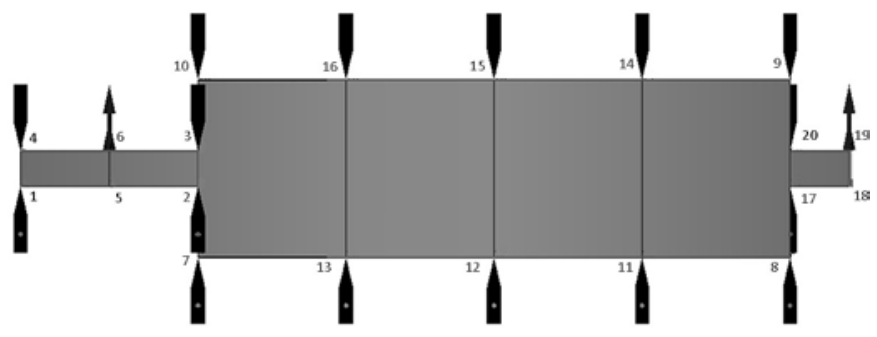

Fig. 11. The measurement points distribution

rates of structural damping by applying PUR foam filling of the hollow regions of the construction which will solve the problem of too much noise of the cylinder unit.

Experimental modal analysis was performed on the test rig presented in Fig. 10. The cylinder unit was supported in two holders in the places where the unit is normally supported in the whole construction of the lift. The way of supporting was not the same as in target construction because not the whole cylindrical surfaces are fixed. Nevertheless the mass of the whole unit is so high that it should influence obtained results insignificantly.

The response accelerometer was placed in the middle of the cylinder generating line. The hammer impact points were distributed evenly along the generating line symmetrically on both sides of the cylinder in one plane. The measurement points distribution is presented in Fig. 11. The impact points are indicated with black hammer symbols, the supporting points are indicated with arrows and the response accelerometer is placed in point number 15 .

The hollow cylinder unit was analyzed modally three times. All the attempts gave similar results of the structural vibration properties of the cylinder unit system. The analysis showed that there are three main modes which are dominant for the whole unit construction. The magnitude of FRF H1 estimate for the point situated opposite the response accelerometer for the hollow cylinder unit is presented in Fig. 12.

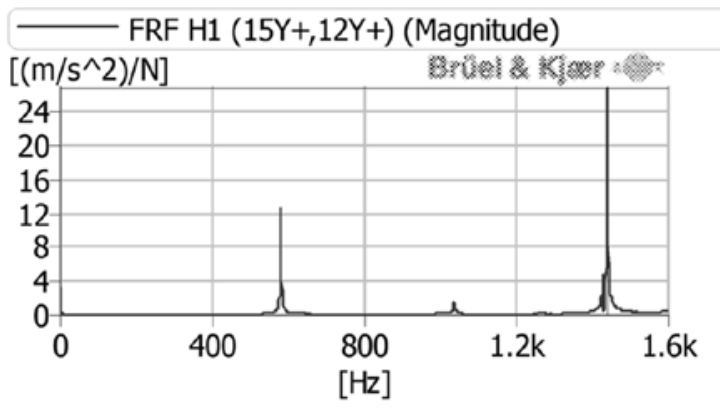

Fig. 12. The magnitude of FRF H1 spectrum of the hollow cylinder unit

The resultant frequencies and $\mathrm{H} 1$ magnitudes of three main modes are as follows:

- The first mode $\mathrm{f}=580[\mathrm{~Hz}]$

- The second mode $\mathrm{f}=1035[\mathrm{~Hz}]$

- The third mode $\mathrm{f}=1439[\mathrm{~Hz}]$

$|\mathrm{H} 1|=12.61\left[\mathrm{~m} / \mathrm{s}^{2} / \mathrm{N}\right]$,

$|\mathrm{H} 1|=1.49\left[\mathrm{~m} / \mathrm{s}^{2} / \mathrm{N}\right]$,

$|\mathrm{H} 1|=26.83\left[\mathrm{~m} / \mathrm{s}^{2} / \mathrm{N}\right]$.

The graphical form of the modes are presented in Fig. 13, 14 and 15.

After filling the cylinder with PUR foam and curing time of one day the analysis was performed again in the same arrangements of impact and response points.

The magnitude of FRF H1 estimate for the point situated opposite the response accelerometer is presented in Fig. 16.

The results obtained after modal analysis are as follows:

- The first mode $\mathrm{f}=577[\mathrm{~Hz}] \quad|\mathrm{H} 1|=3.51\left[\mathrm{~m} / \mathrm{s}^{2} / \mathrm{N}\right]$,

- The second mode $\mathrm{f}=1038[\mathrm{~Hz}] \quad|\mathrm{H} 1|=0.70\left[\mathrm{~m} / \mathrm{s}^{2} / \mathrm{N}\right]$,

- The third mode $\mathrm{f}=1436[\mathrm{~Hz}] \quad|\mathrm{H} 1|=2.35\left[\mathrm{~m} / \mathrm{s}^{2} / \mathrm{N}\right]$. 


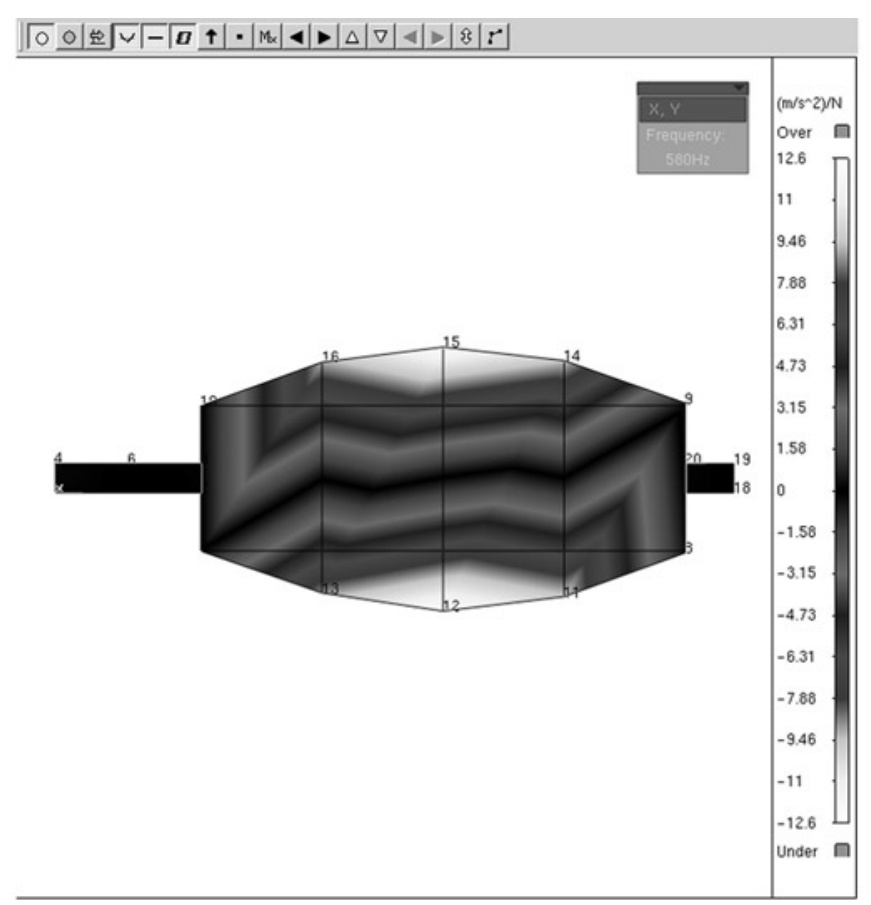

Fig. 13. The first mode of the hollow cylinder unit

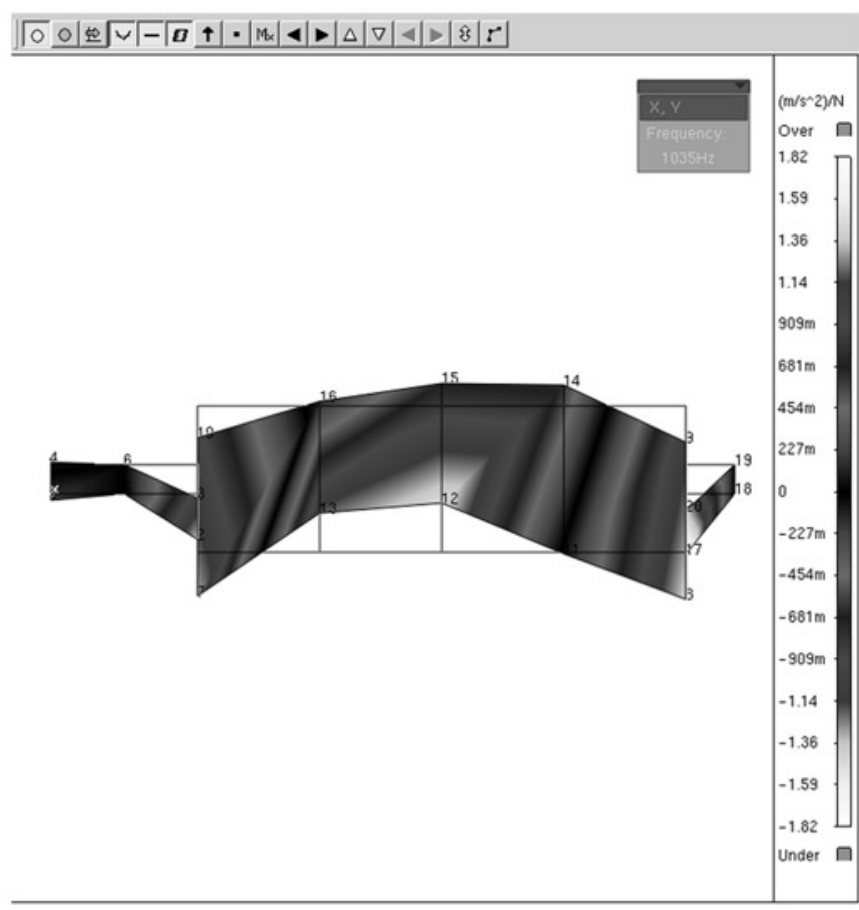

Fig. 14. The second mode of the hollow cylinder unit

The graphical form of the modes are presented in Fig. 17, 18 and 19.

The results of magnitude of FRF H1 of the hollow and filled cylinder unit are presented in Fig. 20.

The procedure of experimental modal analysis was repeated on the next day, after two days of foam curing. The results which were obtained after two days of curing fully correspond to those after one day, which proved that curing time of one day is sufficient to obtain result of structural damping properties enhancement.

The results (Fig. 20) show that the filled cylinder unit vibrates less intensively than it can be noted in the case of the hollow cylinder unit. During experimental part of the research it could be heard by ear that

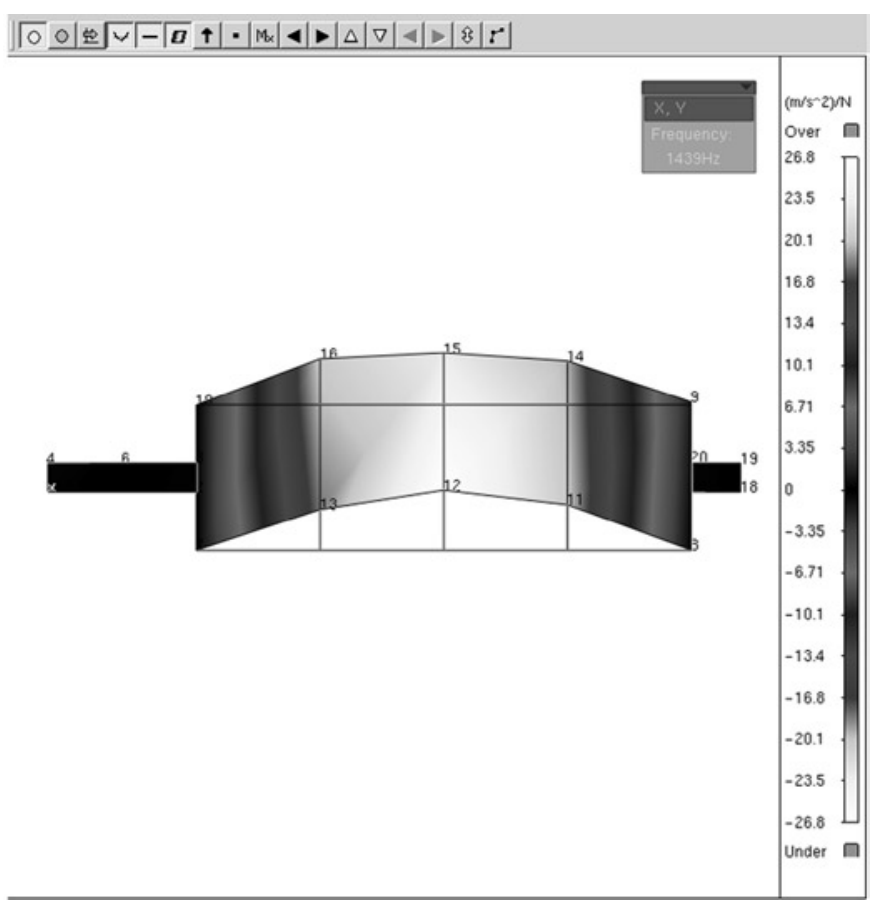

Fig. 15. The third mode of the hollow cylinder unit

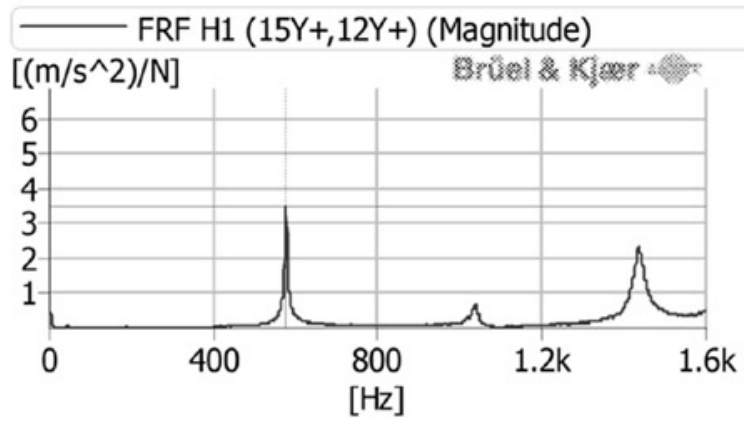

Fig. 16. The magnitude of FRF H1 spectrum of the PUR foam filled cylinder unit

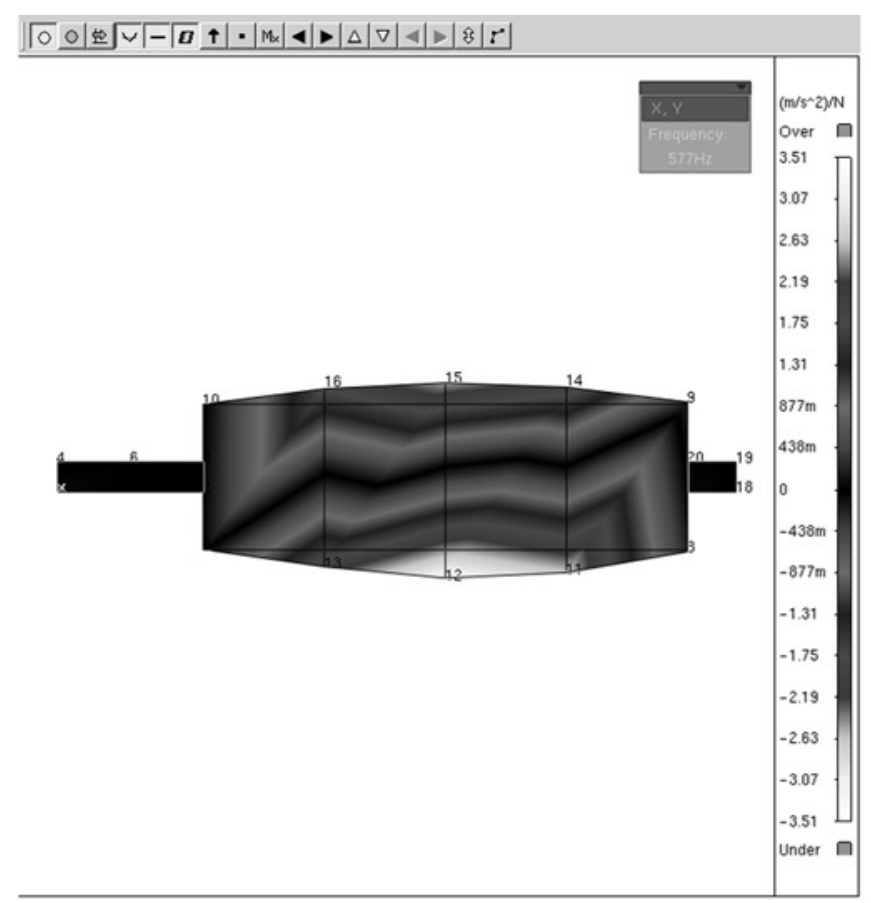

Fig. 17. The first mode of the filled cylinder unit 


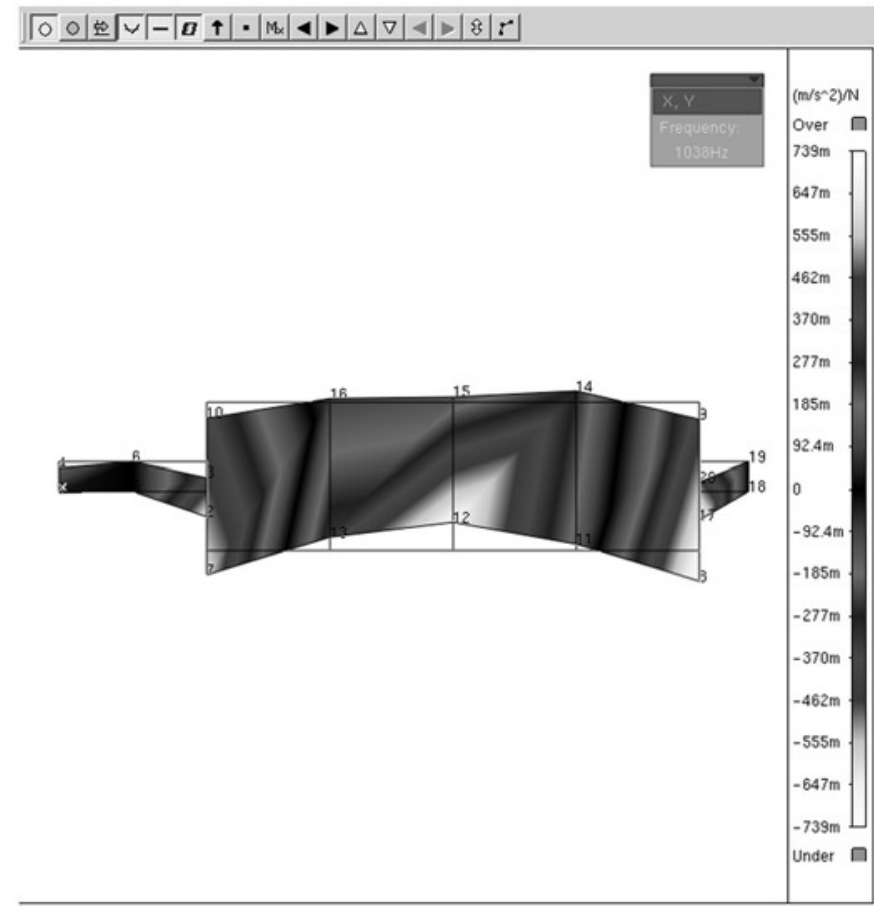

Fig. 18. The second mode of the filled cylinder unit

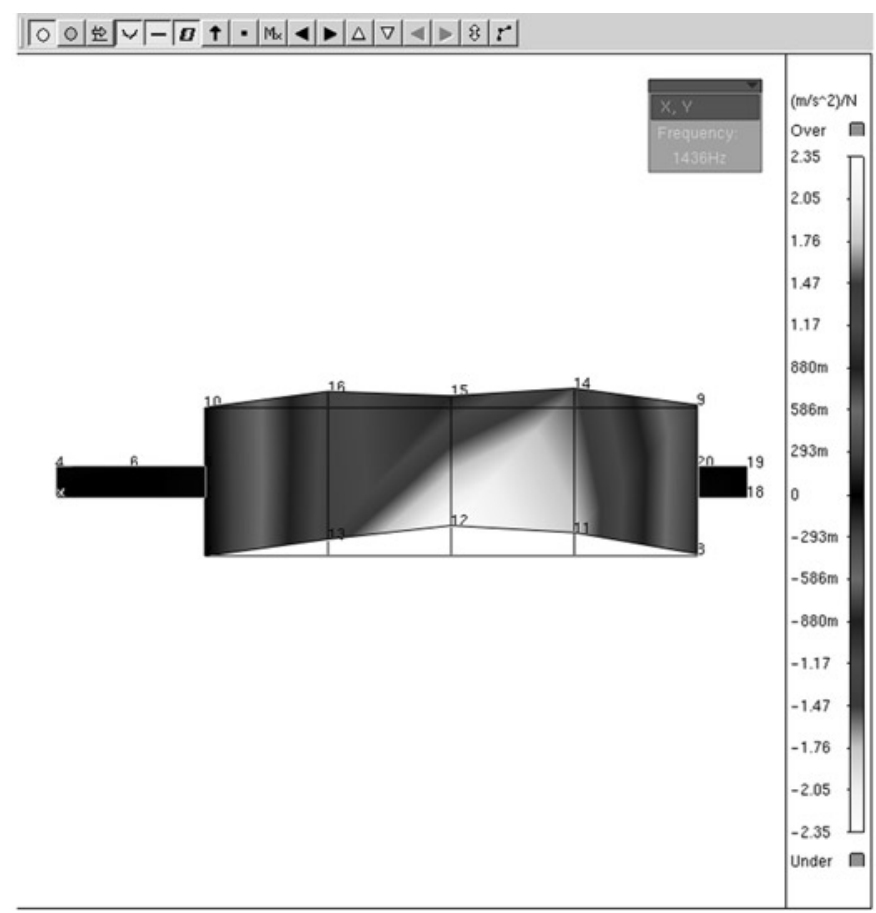

Fig. 19. The third mode of the filled cylinder unit

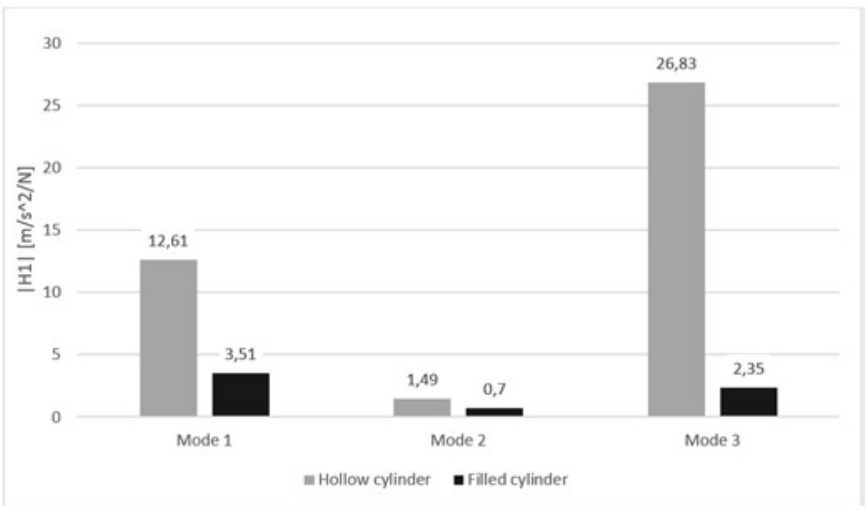

Fig. 20. The magnitude of FRF H1 of the hollow and filled cylinder unit

the impacts sounded muffled after filling the cylinder with PUR foam. The experimental modal results fully supported the sensual effects.

\section{Conclusions}

The results obtained in numerical and experimental modal analysis showed that filling the cylinder with PUR foam of low-expansibility appeared to be very efficient solution for noise and vibration problem of the cylinder unit of lift mechanism. The method of PUR foam application seems to be very easy to perform and low-cost soundproofing method.

Both numerical and experimental modal analysis procedures applied in that case fully supported the thesis of the enhancing the construction damping capabilities by inserting the material of PUR foam of low-expansibility into the hollow regions of resonant structure. The results of the research are of great value for the cylinder manufacturer making his product competitive and high-quality with only a slight additional workload and cost.

\section{Acknowledgement:}

The paper was supported in part by the project MŠMT EUREKA CZ LF13009, E!6727 and by the project LO1201 obtained through the financial support of the Ministry of Education, Youth and Sports of Czech Republic in the framework of the targeted support of the "National Programme for Sustainability I" and the OPR\&DI project Centre for Nanomaterials, Advanced Technologies and Innovation CZ.1.05/2.1.00/01.0005.

\section{References}

1. Chomette, B., and Carrou, J-L., Operational Modal Analysis Applied to the Concert Harp. Mechanical Systems and Signal Processing 2015: 81-91, http://dx.doi.org/10.1016/j.ymssp.2014.10.011.

2. Brecher, Ch., Baumler, S., and Guralnik, A. Experimental Modal Analysis Using a Tracking Interferometer. CIRP Annals - Manufacturing Technology 2014: 345-348.

3. Ebrahimi, R., Esfahanian, M., and Ziaei-Rad, S. Vibration Modeling and Modification of Cutting Platform in a Harvest Combine by Means of Operational Modal Analysis (OMA). Measurement 2013: 3959-3967, http://dx.doi.org/10.1016/j.measurement.2013.07.037.

4. Ewins, D.J. Modal Testing: Theory and Practice. Research Studies Press, 2nd edition, UK, 2000.

5. Gagnol, V., Le, T.P., and Ray, P. Modal Identification of Spindle-tool Unit in High-speed Machining. Mechanical Systems and Signal Processing 2011: 238-239, http://dx.doi.org/10.1016/j.ymssp.2011.02.019. 
6. He, J., and Fu, Z., Modal Analysis. Butterworth-Heinemann, 2001.

7. Li, B., Cai, H., Mao, X., Huang, J., and Luo, B., Estimation of CNC Machine Tool Dynamic Parameters Based on Random Cutting Excitation Through Operational Modal Analysis. International Journal of Machine Tools \& Manufacture 2013: 26-40, http://dx.doi.org/10.1016/j. ijmachtools.2013.04.001.

8. Kęcik K., Rusinek R., and Warminski J., Modelling of high-speed milling process with frictional effect. Journal of Muti-body Dynamics, Proceedings of the Institution of Mechanical Engineers Part K, 2013; 1(1): 3-11, doi:10.1177/1464419312458636.

9. Matsuo, M., Yasui, T., Inamura, T., and Matsumura, M. High-speed Test of Thermal Effects for a Machine Tool Structure Based on Modal Analysis. Precision Engineering 1986: 72-78, http://dx.doi.org/10.1016/0141-6359(86)90089-9.

10. Nangolo, N.F., Soukup, J., Rychlikova, L., and Skocilas, J. A Combined Numerical and Modal Analysis on Vertical Vibration Response of Railway Vehicle. Procedia Engineering 2014: 310-319, http://dx.doi.org/10.1016/j.proeng.2014.12.136.

11. Rahmatalla, S., Hudson, K., Liu, Y., and Eun, H.Ch. Finite Element Modal Analysis and Vibration-waveforms in Health Inspection of Old Bridges. Finite Elements in Analysis and Design, 2014: 40-46, http://dx.doi.org/10.1016/j.finel.2013.09.006.

12. Rusinek R., Stability criterion for aluminium alloy milling expressed by recurrence plot measures. Proceedings of the Institution of Mechanical Engineers, Part B, Journal of Engineering Manufacture 2012; 226 (12): 1976-1985, http://dx.doi.org/10.1177/0954405412462779.

13. Uhl T. Komputerowo wspomagana identyfikacja modeli konstrukcji mechanicznych. Warszawa: WNT, 1997.

14. Vivo, A., Brutti, C., and Leofanti, J. Modal Shape Identification of Large Structure Exposed to Wind Excitation by Operational Modal Analysis Technique. Mechanical Systems and Signal Processing 2013: 195-206, http://dx.doi.org/10.1016/j.ymssp.2013.03.025.

15. Zaghbani, I., and Songmene, V. Estimation of Machine Tool Dynamic Parameters During Machining Operation Through Operational Modal Analysis. International Journal of Machine Tools \& Manufacture 2009: 947-957, http://dx.doi.org/10.1016/j.ijmachtools.2009.06.010.

16. Zhang, G.P., Huang, Y.M., Shi, W.H., and Fu, W.P. Predicting Dynamic Behaviours of a Whole Machine Tool Structure Based on Computer-aided Engineering. International Journal of Machine Tools \& Manufacture 2003: 699-706, http://dx.doi.org/10.1016/S08906955(03)00026-9.

17. Product Data. Pocket Front-end, Type 3560 L, PULSE Lite Software, Types 7781, 7782, 7783. Brüel\&Kjær, 2005.

18. Product Data. DeltaTron ${ }^{\circledR}$ Accelerometers, Types 4514, 4514-001, 4514-002, 4514-004, 4514-B, 4514-B-001, 4514-B-002 and 4514-B-004. Brüel\&Kjær, 2006.

19. Product Data. Impact Hammers - Types 8206, 8206-001, 8206-002 and 8206-003. Brüel\&Kjær, 2006.

Witold PAWLOWSKI

Institute of Machine Tools and Production Engineering

Lodz University of Technology

ul. Stefanowskiego 1/15, 90-924 Lodz, Poland

\section{Lukasz KACZMAREK}

Institute of Material Science and Engineering

Lodz University of Technology

ul. Stefanowskiego 1/15, 90-924 Lodz, Poland

\section{Petr LOUDA}

Institute for Nanomaterials, Advanced Technologies and Innovation Technical University of Liberec

Bendlova 1407/7, 461-17 Liberec 1, Czech Republic

E-mails: witold.pawlowski@p.lodz.pl, lukasz.kaczmarek@p.lodz.pl, petr.louda@tul.cz 